\title{
Keragaman Konsumsi Keluarga TKI dan Keluarga Non TKI Desa Curahnongko Kecamatan Tempurejo Kabupaten Jember
}

\author{
(Diversity Consumption Of TKI Family and Non-TKI Family Of Curahnongko \\ Village,Tempurejo Sub-District, Jember District)
}

\author{
Naufilatul Qomariyah, Sunlip Wibisono, Rafael Purtomo* \\ Jurusan Ilmu Ekonomi Studi Pembangunan, Fakultas Ekonomi dan Bisnis, Universitas Jember (UNEJ) \\ Jln. Kalimantan 37, Jember 68121 \\ E-mail: rafaelpurtomosomaji@yahoo.co.id
}

\begin{abstract}
Abstrak
Penelitian ini bertujuan untuk mengetahui bagaimana keragaman konsumsi keluarga TKI dan keluarga Non TKI, dan seberapa besar pengaruh remiten terhadap konsumsi keluarga TKI yang meliputi konsumsi belanja modal, konsumsi pangan, konsumsi non pangan dan konsumsi total. Serta seberapa besar pengaruh pendapatan terhadap konsumsi keluarga Non TKI yang meliputi konsumsi belanja modal, konsumsi pangan, konsumsi non pangan, dan konsumsi total. Untuk mencapai tujuan tersebut digunakan data primer yang diperoleh langsung dari tempat penelitian. Metode analisis yang digunakan dalam penelitian ini adalah adalah Analisis Regresi Linier Sederhana. Hasil penelitian ini menunjukkan bahwa variabel remiten memiliki pengaruh positif terhadap konsumsi belanja modal, konsumsi pangan, konsumsi non pangan, dan konsumsi total keluarga TKI. Variabel remiten juga memiliki pengaruh yang signifikan terhadap konsumsi belanja modal, konsumsi pangan, konsumsi non pangan, dan konsumsi total keluarga TKI. Variabel pendapatan memiliki pengaruh positif terhadap konsumsi belanja modal, konsumsi pangan, konsumsi non pangan, dan konsumsi total keluaega Non TKI. Dan varaibel pendapatan juga memiliki pengaruh yang signifikan terhadap konsumsi belanja modal, konsumsi pangan, konsumsi non pangan, dan konsumsi total keluarga Non TKI.
\end{abstract}

Kata Kunci: Keragaman konsumsi, remiten, Pendapatan, Konsumsi Belanja Modal, Konsumsi Pangan, Konsumsi Non Pangan, Konsumsi Total.

\begin{abstract}
This study aims to find out how the diversity of family consumption of migrant workers and non migrant workers, and how much influence the remittance to the consumption of family of migrant workers covering consumption of capital expenditure, food consumption, non-food consumption and total consumption. And how much influence the income on the consumption of non-migrant family which includes consumption of capital expenditure, food consumption, non-food consumption, and total consumption. To achieve these objectives used primary data obtained directly from the place of study. The method of analysis used in this research is Simple Linear Regression Analysis. The results of this study indicate that remittance variable has a positive influence on consumption of capital expenditure, food consumption, non-food consumption, and total consumption of families of migrant workers. And remittance variables also have a significant influence on consumption of capital expenditure, food consumption, non-food consumption, and total consumption of families of migrant workers.. The income variable has a positive effect on consumption of capital expenditure, food consumption, non-food consumption, and total consumption of Non-migrant family workers. And income variables also have a significant effect on consumption of capital expenditure, food consumption, non-food consumption, and total consumption of Non-migrant family workers.
\end{abstract}

Keywords: Consumption, Remittance, Revenue, Capital Expenditure Consumption, Food Consumption, Non-Food Consumption, Total Consumption.

\section{Pendahuluan}

Konsumsi menurut Keynes dikenal dengan Hipotesis Pendapatan Absolut (Absolute income hypothesis) yang pada intinya menjelaskan bahwa konsumsi seseorang dan atau masyarakat secara absolut ditentukan oleh tingkat pendapatan, kalaupun ada faktor lain yang juga menentukan, maka menurut Keynes kesemuanya itu tidak berarti apa-apa dan sangat tidak menentukan. Keynes menjelaskan bahwa konsumsi saat ini sangat dipengaruhi oleh pendapatan disposable saat ini. Menurut Keynes, ada batas konsumsi minimal yang tidak tergantung tingkat pendapatan. Artinya tingkat konsumsi tersebut harus terpenuhi, walaupun tingkat pendapatan sama dengan nol. Itulah yang disebut dengan konsumsi otonomus. Jika pendapatan disposable meningkat, maka konsumsi juga meningkat. Hanya saja peningkatan tersebut tidak sebesar peningkatan pendapatan disposable (Wijayanomics.Wordpress).

Pendapatan adalah seluruh penerimaan seseorang sebagai imbalan jasa yang telah dicurahkan untuk orang lain atau badan organisasi baik dalam bentuk uang maupun fasilitas dalam jangka waktu tertentu. Pendapatan pada dasarnya meurpakan sumber utama penghasilan seseorang. Sebab itu, pendapatan harus cukup untuk memenuhi kebutuhan hidup pekerja dan keluarganya (Soeroto,2002:183).

Pendapatan merupakan salah satu indikator yang bisa dipakai mengukur tingkat kemakmuran penduduk suatu daerah dalam jangka waktu tertentu. Didalam ekonomi makro, pendapatan dibagi atas beberapa pendapatan diantaranya pendapatan relatif, pendapatan pribadi, pendapatan nasional dan pendapatan disposibel (Muin,2010:10).

\footnotetext{
* Corresponding author
} 
Sumber utama penghasilan seseorang adalah pendapatan. Oleh karena itu pendapatan harus cukup untuk memenuhi kebutuhan pekerjaan pekerja dan keluarganya dengan wajar. Kewajaran dapat dinilai dan diukur dengan kebutuhan hidup minimum atau sering disebut dengan kebutuhan fisik. Kenyataan menunjukkan bahwa masih banyak pekerja indonesia berpenghasilan sangat kecil, lebih kecil dari kebutuhan hidup minimummya (Simanjuntak, 1998 : 133).

Tingkat kesuksesan tenaga kerja Indonesia yang bekerja di luar Negeri setelah kembali ke tanah air sangat erat kaitannya dengan pemanfaatan hasil yang diperoleh selama bekerja di luar negeri. Oleh karena itu penting bagi pemerintah untuk mendayagunakan potensi, baik potensi ekonomi maupun sumber daya manusia, dari pada migran kembali tersebut. Dalam membuat perencanaan kebijaksanaan dan program pemanfaatan potensi dari migran kembali, ada dua hal yang perlu di telaah yaitu (1) karakteristik sosial ekonomi dari para migran kembali, dan (2) pemanfaatan remiten yang dikirim oleh migran selama mereka bekerja d luar negeri. Disamping itu untuk meningkatkan peranan migrasi internasional dari tenaga kerja Indonesia maka kebijaksanaan pemanfaatan potensi TKI atau migrasi internasional bagi kegiatan pembangunan nasional hendaknya direncanakan secara lebih menyeluruh

Arus migrasi berkembang antar negara disebabkan adanya beberapa faktor yang mempengaruhi, baik faktor pendorong maupun faktor penarik. Faktor pendorong merupakan faktorfaktor yang berasal dari negara asal untuk bekerja ke luar negeri, seperti rendahnya tingkat upah, kurangnya lapangan pekerjaan, kurangnya lahan pertanian dan tingginya tingkat persaingan didunia pekerjaan. Sedangkan untuk faktor penarik merupakan faktor-faktor yang beraal dari negara tujuan sehingga penduduk bisa tertarik untuk bekerja di negara tersebut biasanya seperti banyaknya lapangan pekerjaan yang tersedia, tingginya tingkat upah, kesempatan baru, pekerjaan yang lebih baik, keadaan dan lingkungan yang baik dan lain-lain.

Menjadi Tenaga Kerja Indonesia (TKI) adalah salah satu sarana penting untuk mengentaskan kemiskinan dan pengangguran. Menurut Nasution ( 1999) alasan utama para calon TKI meninggalkan kampung halaman untuk bekerja ke luar negeri adalah karena terlalu susah untuk mendapatkan pekerjaan di dalam negeri. Selain karena terlalu susahnya mendapatkan pekerjaan, alasan lain para TKI pergi keluar negeri yaitu untuk mendapatkan penghasilan yang lebih besar dari sebelumnya.

Sementara di Jawa Timur sesuai data dari Badan Pusat Statistik (BPS) jumlah penduduk miskin pada tahun 2013 sebanyak 4893.00 dan presentase penduduk miskin sebanyak 12.73 dengan garis kemiskinan 273 758. Kabupaten jember menjadi urutan ke dua dari 79 kabupaten di Jawa Timur yang mempunyai jumlah penduduk tertinggi setelah kabupaten malang, yaitu sebesar 278, 5 orang.

Kabupaten Jember merupakan salah satu kabupaten di Provinsi Jawa Timur dengan jumlah penduduk miskin tertinggi kedua setelah Kabupaten Malang pada tahun 2013. Kabupaten Jember merupakan kota yang mempunyai laju pertumbuhan yang tinggi. Dengan luas wilayah $3.293,34 \mathrm{~km}$ kuadrat terdiri dari 31 kecamatan dan 248 desa.
Meningkatnya nilai investasi di Kabupaten Jember menyebabkan pertumbuhan ekonomi membaik. Dengan kebutuhan tenaga kerja yang banyak maka persediaan lapangan pekerjaan juga semakin terbuka lebar dengan demikian tingkat pengangguran juga bisa diatasi dengan baik. Akan tetapi hal tersebut hanya terjadi di berbagai wilayah, masih wilayah-wilayah terpencil yang kurang kaan lapangan pekerjaan terutama maysarakat yang kurang akan pendidikan atau jauh dari akses pendidikan. Sehingga masyarakat memilih untuk bekerja ke luar negeri (TKI). Menjadi TKI dianggap dapat mengatasi masalah-masalah perekonomian yang di hadapi oleh maysarakat.

Desa Curahnongko merupakan salah satu desa yang berada di kecamatan Tempurejo Kabupaten Jember. Desa Curahnongko terletak hampir ujung timur selatan yang berbatasan langsung dengan perkebunan PTPN XII. Jenis pekerjaan utama di Desa Curahnongko adalah sebagai petani. Karena kurangnya lahan pertanian, masyarakat yang tidak mempunyai lahan pertanian cenderung bekerja sebagai buruh tani kepada masyarakat lainnya yang mempunyai lahan. Akan tetapi pekerjaan tersebut tidak dapat mencukupi segala kebutuhan para masyarakat Desa Curahnongko. Hasil pertanian yang di dapat hanya cukup untuk kebutuhan konsumsi pangan sehari-hari. Untuk memenuhi kebutuhan lainnya masyarakat harus mencari pengahsilan tambahan dan itu tidak selalu bisa di dapatkan oleh maysrakat. Karena keterbatasan pekerjaan di Desa Curahnongko maka maysrakat memilih untuk bekerja ke luar negeri atau menjadi TKI. Karena menjadi TKI di anggap dapat memperbaiki keadaan perekonomian keluarganya. Hal tersebut dilakukan oleh masyarakat, dan dapat terbukti bahwa dengan menjadi TKI kebutuhan lainnya seperti konsumsi belanja modal, konsumsi non pangan, dan lainnya dapat terpenuhi.

Remitan merupakan gaji atau hasil yang dikirimkan TKI ke daerah asal. Tinggi rendahnya remiten yang dikirim TKI ke daerah asal sangatt berpengaruh terhadap perekonomian masyarakat atau anggota keluarga para TKI. Remiten merupakan sumber yang sangat penting bagi masyarakat Desa Curahnongko. Karena dengan remiten masyarakat Desa Curahnongko bisa memperbaiki kondisi perekonomian keluarga nya yang ada di Desa Curahnongko. Kegunaan remiten sebagian besar digunakan untuk mengkonsumsi belanja modal, seperti investasi, membeli kendaraan bermotor, dan lain-lain. Sangat berbeda dengan pendapatan yang diterima keluarga non TKI, sebagian besar pendapatan yag diterima keluarga non TKI hanya di pergunakan untuk memnuhi konsumsi pangan dalam sehari-hari.Berdasarkan rumusan masalah yang akan di bahas pada penelitian ini, ada beberapa alasan atau tujuan peneliti dalam melakukan penelitian ini yaitu:Untuk mengetahui keragaman konsumsi keluarga TKI dan keluarga Non TKI di Desa Curahnongko Kecamatan Tempurejo Kabupaten Jember,Untuk mengetahui pengaruh remitan terhadap konsumsi belanja modal, konsumsi pangan, konsumsi non pangan dan konsumsi total keluarga TKI di Desa Curahnongko Kecamatan Tempurejo Kabupaten Jember, Untuk mengetahui pengaruh pendapatan terhadap konsumsi belanja modal, konsumsi pangan, konsumsi non pangan dan konsumsi total keluarga non TKI di Desa Curahnongko kecamatan Tempurejo Kabupaten Jember. 


\section{Metode}

\section{Rancangan atau Desain Penelitian}

Jenis penelitian yang dilakukan dalam penelitian ini adalah deskriptif kuantitatif yaitu penelitian yang menggambarkan hasil dari penelitian yang dilakuan, dengan menggunakan data jumlah remiten, jumlah pendapatan, konsumsi belanja modal, konsumsi pangan, konsumsi non pangan, dan konsumsi total keluarga TKI dan keluarga non TKI di Desa Curahnongko.

\section{Jenis dan Sumber Data}

Jenis data yang digunakan dalam penelitian ini adalah data primer yang diperoleh dari hasil observasi dan wawancara

\section{Populasi dan Sampel}

populasi dalam penelitian ini adalah seluruh rumah tangga yang ada di Desa Curahnongko. Dan sampel dalam penelitian ini berjumlah 237 responden dengan teknik penarikan Snowball sampling.

\section{Metode Analisis Data}

Metode analisis data yang digunakan dalam penelitian ini adalah Analisis Regresi Linier Sederhana yaitu untuk mengetahui seberapa besar pengaruh variabel independen terhadap variabel dependen. Untuk mengetahui seberapa besar pengaruh remiten terhadap konsumsi belanja modal, konsumsi pangan, konsumsi non pangan dan konsumsi total serta pengaruh varaibel pendapatan terhadap konsumsi belanja modal, konsumsi pangan, konsumsi non pangan dan konsumsi total. Maka rumus persamaan analisis Regresi Linier Sederhana sebagai berikut:

$$
\begin{aligned}
& \mathrm{Y} 1=\mathrm{b}_{0}+\mathrm{b}_{1} \mathrm{X}_{1}+\mathrm{e} \ldots \ldots .(1) \\
& \mathrm{Y} 2=\mathrm{b}_{0}+\mathrm{b}_{1} \mathrm{X}_{1}+\mathrm{e} \ldots \ldots .(2) \\
& \mathrm{Y} 3=\mathrm{b}_{0}+\mathrm{b}_{1} \mathrm{X}_{1}+\mathrm{e} \ldots \ldots .(3) \\
& \mathrm{Y} 4=\mathrm{b}_{0}+\mathrm{b}_{1} \mathrm{X}_{1}+\mathrm{e} \ldots \ldots .(4)
\end{aligned}
$$

Keterangan:

$\mathrm{Y} 1=$ konsumsi belanja modal

$\mathrm{Y} 2=$ konsumsi pangan

$\mathrm{Y} 3=$ konsumsi non pangan

Y4 = konsumsi total

$\mathrm{X} 1=$ Remiten

$\mathrm{b} 0=$ konstanta

$\mathrm{b} 1=$ koefisien dari remiten

e $=$ error/ penganggu

Pada penelitian ini juga menggunakan uji asumsi klasik yaitu untuk memperoleh suatu model regresi linier sederhana yang bersifat Best Linier Unbiased Estimator (BLUE). Beberapa jenis uji asumsi klasik diantaranya uji heteroskedastisitas, uji autokorelasi. uji normalitas, uji linieritas. Pengelolaan dan analisis data menggunkan program eviews 9 .

\section{Uji Heteroskedastisitas}

Uji Heteroskedastisitas digunakan untuk mengetahui apakah kesalahan pengganggu mempunyai varian yang sama dari masing-masing variabel bebas.

\section{Uji Autokorelasi}

Uji autokorelasi digunakan untuk mengetahui apakah dalam model regresi linier ada korelasi antara kesalahan pengganggu pada periode $\mathrm{t}$ dengan kesalahan penganggu pada periode $\mathrm{t}-1$ (sebelumnya), dimana terjadi korelasi dinamakan ada problem autokorelasi. Untuk melihat nilai uji autokorelasi bisa dilihat dari nilai pro chi-square, jika nilai pro chi-square lebih besar dari alfa (5\%) maka model tersebut empiris dan tidak memiliki masalah autokorelasi. Dan apabila nilai pro chi-square lebih kecil dari nilai alfa (5\%) maka model tersebut tidak empiris dan memiliki masalah autokorelasi.

\section{Uji Normalitas}

Bertujuan untuk menguji apakah model regresi, variabel pengganggu atau residual memiliki distribusi normal. Untuk melihat nilai uji normalitas bisa dilihat dari nilai probability nya, jika nilai probability lebih besar dari alfa (5\%) maka persamaan tersebut berdistribusi normal. Sebaliknya apabila nilai probability lebih kecil dari alfa (5\%) maka persamaan tersebut tidak berdistribusi normal.

\section{Uji Linieritas}

Uji linieritas digunakan untuk melihat apakah spesifikasi model yang digunakan sudah benar atau tidak. Apakah fungsi yang digunakan dalam studi empiris sebaiknya berbentuk linier, kuadrat atau kubik. Dengan uji linieritas akan diperoleh informasi apakah model empiris sebaiknya linier, kuadrat atau kubik. Untuk melihat nilai uji linieritas dapat dilihat dari nilai probability. Jika nilai probability lebih besar dari nilai alfa (5\%) maka model tersebut berbentuk linier, dan apabila nilai probablity lebih kecil dari nilai alfa (5\%) maka model tersebut berbentuk tidak linier.

\section{Hasil dan Pembahasan}

\section{Hasil}

Hasil perhitungan antara variabel terikat (Konsumsi Belanja Modal, Konsumsi Pangan, Konsumsi Non Pangan dan Konsumsi Total) dengan variabel bebas yang terdiri dari remitan dan pendapatan. Dengan menggunakan metode analisis regresi linier sederhana di sajikan pada tabel 1 berikut:

Tabel 1. Hasil Persamaan Regresi Linier Sederhana Keluarga TKI di Desa Curahnongko Kecamatan Tempurejo Kabupaten Jember

\begin{tabular}{llllll}
\hline No & Ket & Konst & Koef & t-stas & Prob \\
\hline 1 & R-KBM & -554283.0 & 0.04100 & 10,86370 & 0,0000 \\
2 & R-KP & 196307.1 & 0.02311 & 2,741686 & 0.0068 \\
3 & R-KNP & -138715 & 0,149773 & 3,641271 & 0,0004 \\
4 & R-KT & -496690.9 & 0,058293 & 8,691921 & 0,0000 \\
\hline
\end{tabular}

Sumber: Lampiran diolah, 2017

Berdasarkan pengolahan data tabel 1 dapat di jelaskan bahwa pada persamaan pertama variabel remitan berpengaruh positif terhadap konsumsi belanja modal dengan nilai koefisien regresi sebesar 0.041004. dan variabel remitan berpengaruh signifikan terhadap konsumsi belanja modal dengan nilai tstatistik 10.86370 dan prob sebesar 0.0000 lebih kecil dari nilai alfa 0.05 . persamaan kedua variabel remitan berpengaruh positif terhadap konsumsi pangan denga nilai koefisien regresi sebesar 0.023111. dan variabel remitan berpengaruh signifikan terhadap konsumsi pangan dengan nilai t-statistik 2.741686 dan prob sebesar 0.0068 lebih kecil 
dari 0.05. persamaan ketiga variabel remitan berpengaruh positif terhadap konsumsi non pangan dengan nilai koefisien regresi sebesar 0.149773. dan variabel remitan berpengaruh signifikan terhadap konsumsi non pangan dengan nilai tstatistik 3.641271 dna prob sebesar 0.0004 lebih kecil dari nilai alfa 0.05 . persamaan keempat variabel remitan berpengaruh positif terhadap konsumsi total dengan nilai koefisien regresi sebesar 0.0582932. dan varaibel remitan berpengaruh signifikan terhadap konsumsi total dengan nilai t-statistik 8.691921 dan nilai prob sebesar 0.0000 lebih kecil dari 0.05 .

Tabel 2. Hasil Persamaan Regresi Linier Sederhana Keluarga Non TKI di Desa Curahnongko Kecamatan Tempurejo Kabupaten Jember

\begin{tabular}{llllll}
\hline No & Ket & Konst & Koef & t-stas & Prob \\
\hline 1 & P-KBM & $-101208,7$ & 0,246338 & 4,448341 & 0,0000 \\
2 & P-KP & 234740,6 & 0,083749 & 2,361997 & 0,0210 \\
3 & P-KNP & $-54899,99$ & 0,227277 & 3,718810 & 0,0004 \\
4 & P-KT & 78631,87 & 0,557363 & 5,276357 & 0,0000
\end{tabular}

Sumber: Lampiran diolah, 2017

Berdasarkan pengolahan data tabel 2 dapat dijelaskan bahwa pada persamaan pertama variabel pendapatan berpengaruh positif terhadap konsumsi belanja modal dengan nilai koefisien 0.246338. dan variabel pendapatan berpengaruh signifikan terhadap konsumsi belanja modal dengan nilai tstatistik sebesar 4.448341 dan nilai prob sebesar 0.0000 lebih kecil dari 0.05 . persamaan kedua variabel pendapatan berpegaruh positif terhadap konsumsi pangan dengan nilai koefisien sebesar 0.083749. dan variabel pendapatan berpengaruh signifikan terhadap konsumsi pangan dengan nilai t-staitistk sebesar 2.361997 dan nilai prob sebesar 0.0210 lebih kecil dari nilai 0.05 . persamaan ketiga variabel pendapatan berpengaruh positif terhadap konsumsi non pangan dengan nilai koefisien sebesar 0.227277. dan variabel pendapatan berpengaruh signifikan terhadap konsumsi non pangan dengan nilai t-statistik sebesar 3.718810 dan nilai prob sebesar 0.0004 lebih kecil dari 0.05 . persamaan ke empat variabel pendapatan berpengaruh positif terhadap konsumsi total dengan nilai koefisien sebesar 0.557363. dan variabel pendapatan berpengaruh signifikan terhadap konsumsi total dengan nilai t-statistik sebesar 5.276357 dan nilai prob sebesar 0.0000 lebih kecil dari 0.05 .

\section{Uji Heteroskedastisitas}

Berikut hasil estimasi dari uji heteroskedastisitas antara variabel remiten dengan variabel konsumsi belanja modal, konsumsi pangan, konsumsi non pangan dan konsumsi total pada tabel 3 sebagai berikut:

Tabel 3. Hasil Uji Heteroskedastisitas Remiten

\begin{tabular}{llllll}
\hline No & Ket & F-statistik & Prob.F & Obs*R-sq & Prob.Chi \\
\hline 1 & R-KBM & 0,138048 & 0,7107 & 0,139624 & 0,7087 \\
2 & R-KP & 1,255762 & 0,2641 & 1,261452 & 0,2614 \\
3 & R-KNP & 0,203698 & 0,6524 & 0,205940 & 0,6500 \\
4 & R-KT & 0,057896 & 0,8102 & 0,058585 & 0,8087 \\
\hline
\end{tabular}

Sumber: Lampiran diolah, 2017
Berdasarkan tabel 3 dari hasil uji heteroskedastisitas dengan menggunakan uji ARCH dijelaskan bahwa nilai Prob. Chisquare remiten terhadap konsumsi belanja modal (0.7087) lebih besar dari ( $\alpha=0.05)$, hal ini menunjukkan bahwa model empiris tersebut tidak terdapat masalah heteroskedastisitas. nilai Prob. Chi-square remiten terhadp konsumsi pangan (0.2616) lebih besar dari $(\alpha=0.05)$,hal ini menunjukkan bahwa model empiris tersebut tidak terdapat masalah heteroskedastisitas. Nilai Prob.Chi-square remitan terhadap konsumsi non pangan (0.6500) lebih besar dari nilai $(\alpha$ $=0.05$ ), hal ini menunjukkan bahwa model empiris tersebut tidak terdapat masalah heteroskedastisitas. Dan nilai Prob. Chi-square pengaruh remitan terhdap konsumsi total (0.8087) lebih besar dari $(\alpha=0.05)$, hal ini menunjukkan bahwa model empiris tersebut tidak terdapat masalah heteroskedastisitas.

Berikut hasil estimasi dari uji heteroskedastisitas antara variabel pendapatan terhadap variabel konsumsi belanja modal, konsumsi pangan, konsumsi non pangan dan konsumsi total sebagai berikut: Berdasarkan tabel 4 nilai Prob.Chi-squared pengaruh pendapatan terhadap konsumsi belanja modal sebesar ( 0.8806$)$ lebih besar dari $(\alpha=0.05)$, hal ini menunjukkan bahwa model empiris tersebut tidak terdapat masalah heteroskedastisitas. Nilai Prob.Chi-squared pengaruh pendapatan terhadap konsumsi pangan sebesar (0.6264) lebih besar dari nilai alpha 0.05 , hal ini menunjukkan bahwa model empiris tersebut tidak terdapat masalah heteroskedastisitas.

Tabel 4. Hasil Uji Heteroskedastisitas Pendapatan

\begin{tabular}{llllll}
\hline No & Ket & F-statistik & Prob.F & Obs*R-sq & Prob.Chi \\
\hline 1 & P-KBM & 0,021914 & 0,8828 & 0,022552 & 0,8806 \\
2 & P-KP & 0,230921 & 0,6324 & 0,236908 & 0,6264 \\
3 & P-KNP & 0,000772 & 0,9779 & 0,000795 & 0,9775 \\
4 & P-KT & 0,028943 & 0,8654 & 0,029781 & 0,8630 \\
\hline
\end{tabular}

Sumber: Lampiran diolah, 2017

Nilai Prob. Chi-squared pengaruh pendapatan terhadap konsumsi non pangan sebesar (0.9775) lebih besar dari nilai alpha 0.05. hal ini menunjukkan bahwa model empiris tersebut tidak terdapat masalah heteroskedastisitas. Nilai Prob.Chi-squared pengaruh pendapatan terhadap konsumsi total sebesar (0.8630) lebih besar dari nilai alpha 0.05 , hal ini menunjukkan bahwa model empiris tersebut tidak terdapat masalah heteroskedastisitas.

\section{Uji Autokorelasi}

Berdasarkan hasil estimasi dari Uji Autokorelasi antara variabel remitan terhadap variabel konsumsi belanja modal,konsumsi pangan, konsumsi non pangan dan konsumsi total pada tabel 5 sebagai berikut:

Tabel 5. Hasil Uji Autokorelasi Remiten

\begin{tabular}{llllll}
\hline No & Ket & F-statistik & Prob.F & Obs*R-sq & Prob.Chi \\
\hline 1 & R-KBM & 0,068140 & 0,9342 & 0,139528 & 0,9326 \\
2 & R-KP & 2,027852 & 0,1349 & 4,054343 & 0,1317 \\
3 & R-KNP & 1,596265 & 0,2058 & 3,208136 & 0,2011 \\
4 & R-KT & 2,068051 & 0,1298 & 4,132724 & 0,1266 \\
\hline
\end{tabular}

Sumber: Lampiran diolah,2017 
Berdasarkan tabel 5 dari hasil uji autokorelasi nilai Prob. Chisquared pengaruh remitan terhadap konsumsi belanja modal sebesar (0.9326) lebih besar dari nilai alpha 0.05 , artinya hal ini menunjukkan bahwa model empiris tersebut tidak terdapat masalah autokorelasi. hasil uji autokorelasi nilai Prob.Chisquared pengaruh remitan terhadap konsumsi pangan sebesar (0.1317) lebih besar dari nilai alpha 0.05, hal ini menunjukkan bahwa model empiris tersebut tidak terdapat masalah autokorelasi. dari hasil uji autokorelasi nilai Prob. Chi-squared (0.2011) pengaruh remitan terhadap konsumsi nonn pangan lebih besar dari nilai alpha 0.05 , hal ini menunjukkan bahwa model empiris tersebut tidak terdapat masalah autokorelasi. Dan hasil uji autokorelasi nilai prob. Chi-squared pengaruh remitan terhadap konsumsi total sebesar (0.1266) lebih besar dari nilai alpha, hal ini menunjukkan bahwa model empiris tersebut tidak terdapat masalah autokorelasi.

Berikut hasil estimasi dari uji autokorelasi antara variabel pendapatan terhadap variabel konsumsi belanja modal, konsumsi pangan, konsumsi non pangan dan konsumsi total pada tabel 6 sebagai berikut:

Tabel 6. Hasil Uji Autokorelasi antara variabel pendapatan

\begin{tabular}{llllll}
\hline No & Ket & F-statistik & Prob.F & Obs*R-sq & Prob.Chi \\
\hline 1 & P-KBM & 0,547320 & 0,5811 & 1,141345 & 0,5651 \\
2 & P-KP & 1,390528 & 0,2560 & 2,829635 & 0,2430 \\
3 & P-KNP & 1,135730 & 0,3273 & 2,328240 & 0,3122 \\
4 & P-KT & 0,779642 & 0,4627 & 1,614794 & 0,4460
\end{tabular}

Sumber: Lampiran diolah, 2017

Berdasarkan tabel 6 dari hasil uji autokorelasi nilai Prob.Chisquared pengaruh pendapatan terhadap konsumsi barang modal sebesar $(0.5651)$ lebih besar dari nilai alpha 0.05 , hal ini menunjukkan bahwa model empiris tersebut tidak terjadi masalah autokorelasi. nilai Prob.Chi-squared pengaruh pendapatan terhadap konsumsi pangan sebesar $(0,2430)$ lebih besar dari nilai alpha 0.05 , hal ini menunjukkan bahwa model empiris tersebut tidak terjadi masalah autokorelasi. nilai Prob.Chi-squared pengaruh pendapatan terhadap konsumsi non pangan sebesar $(0.3122)$ lebih besar dari nilai alpha 0.05 , hal ini menunjukkan bahwa model empiris tersebut tidak terjadi masalah autokorelasi. nilai Prob. Chi squared pengaruh pendapatan terhadap konsumsi total sebesar (0.4460) lebih besar dari nilai alpha 0.05, hal ini menunjukkan bahwa model empiris tersebut tidak terjadi masalah autokorelasi.

\section{Uji Normalitas}

Uji normalitas data dilakukan untuk mengetahui apakah data yang ada dalam variabel penelitian berdistribusi normal atau tidak. Dengan nilai alpha 5\% atau 0.05. Berikut hasil uji normalitas data antara variabel remitan terhadap variabel konsumsi belanja modal, konsumsi pangan, konsumsi non pangan dan konsumsi total dan antara variabel pendapatan terhadap varibel konsumsi belanja modal, konsumsi pangan, konsumsi non pangan dan konsumsi total sebagai berikut: Berdasarkan tabel uji normalitas, dapat dijelaskan bahwa nilai probability yang berdistribusi normal terletak pada persamaan pengaruh pendapatan terhadap konsumsi pangan keluarga non TKI, yaitu nilai probability nya sebesar $0.148905>0.05$, artinya model empiris tersebut menunujukkan bahwa berdistribusi normal. untuk persamaan pertama pengaruh remitan terhadap konsumsi barang modal nilai probability sebesar 0.000000 lebih kecil dari 0.05 artinya model empiris tersebut tidak berdistribusi normal.Persamaan kedua pengaruh remitan terhadap konsumsi pangan nilai probability sebesar 0.591628 lebih besar dari 0.05 artinya model empiris tersebut berdistribusi normal. untuk persamaan ketiga pengaruh remitan terhadap konsumsi non pangan nilai probability sebesar 0.127517 lebih besar dari 0.05 artinya model empiris tersebut berdistribusi normal. untuk persamaan keempat pengaruh remitan terhadap konsumsi total nilai probability sebesar 0.000000 lebih kecil dari 0.05 artinya model empiris tersebut tidak berdistribusi normal. untuk persamaan kelima pengaruh pendapatan terhadap konsumsi barang modal nilai probability sebesar 0.000000 lebih kecil dari 0.05 artinya model empiris tersebut tidak berdistribusi normal. untuk persamaan ke tujua pengaruh pendapatan terhadap konsumsi non pangan nilai probability sebesar 0.069667 lebih besar dari 0.05 , artinya model empiris tersebut berdistribusi normal. dan untuk persamaan terakhir pengaruh pendapatan terhadap konsumsi total nilai probability sebesar 0.149992 lebih besar dari 0.05 artinya model empiris tersebut berdistribusi normal.

Tabel 7. Hasil Uji Normalitas keluarga TKI dan keluarga Non TKI

\begin{tabular}{lll}
\hline No & Variabel & Keterangan \\
\hline 1 & R-KBM & $\begin{array}{l}\text { Jarque-Bera }=146,8849 \\
\text { Probability }=0,000000\end{array}$ \\
2 & R-KP & $\begin{array}{l}\text { Jarque-Bera }=553,7287 \\
\text { Probability }=0,591628^{*}\end{array}$ \\
3 & R-KNP & $\begin{array}{l}\text { Jarque-Bera }=34740,88 \\
\text { probability }=0,127517^{*}\end{array}$ \\
4 & R-KT & $\begin{array}{l}\text { Jarque-Bera }=10503,43 \\
\text { Probability }=0,000000\end{array}$ \\
5 & P-KBM & $\begin{array}{l}\text { Jarque-Bera }=4480,620 \\
\text { Probability }=0,000000\end{array}$ \\
6 & P-KP & $\begin{array}{l}\text { Jarque-Bera }=3,808897 \\
\text { Probability }=0,148905^{*}\end{array}$ \\
7 & P-KNP & $\begin{array}{l}\text { Jarque-Bera }=2450,675 \\
\text { Probability }=0,069667^{*}\end{array}$ \\
& P-KT & $\begin{array}{l}\text { Jarque-Bera }=3,794350 \\
\text { Probability }=0,149992^{*}\end{array}$ \\
\hline
\end{tabular}

Sumber: Lampiran Diolah, 2017

\section{Uji Linieritas}

Uji linieritas dilakukan untuk melihat apakah persamaan tersebut $\mathrm{b}$ erbentuk linier atau tidak, dengan ketentuan alpha atau tingkat signifikan sebesar $5 \%$ atau 0.05 . berikut tabel uji linieritas antara variabel remiten terhadap variabel konsumsi belanja modal, konsumsi pangan, konsumsi non pangan dan konsumsi total sebagai berikut: 
Tabel 8. Hasil Uji Linieritas Keluarga TKI

\begin{tabular}{llllll}
\hline No & Ket & t-statistik & Prob. & F-statistik & Prob. \\
\hline 1 & R-KBM & 5,896340 & 0,0000 & 34,76683 & 0,0000 \\
2 & R-KP & 1,315379 & 1,1902 & 1,730222 & $0,1902^{*}$ \\
3 & R-KNP & 2,240674 & 0,0264 & 5,020620 & $0,0264^{*}$ \\
4 & R-KT & 8,202057 & 0,0000 & 67,27374 & 0,0000
\end{tabular}

Sumber: Lampiran diolah, 2017

Berdasarkan tabel diatas, hasil uji linieiritas data untuk keluarga TKI dari empat persamaan terdapat satu persamaan yang berbentuk linier. Persamaan pertama nilai Probability Fstatistik sebesar 0.0000 lebih kecil dari 0.05 artinya model tersebut tidak berbentuk fungsi linier atau tidak linier.Untuk persamaan kedua nilai probability F-statistik sebesar 0.1902 lebih besar dari 0.05 artinya model tersebut benbentuk fungsi linier atau tidak linier. Untuk persamaan ke tiga nilai Probability F-statistik sebesar 0.0264 lebih besar dari 0.05, artinya model tersebut berbentuk fungsi linier. Dan untuk persamaan terakhir untuk keluarga TKI nilai Probability Fstatistik sebesar 0.0000 lebih kecil dari 0.05 , artinya model tersebut berbentuk tidak linier.

Berikut hasil estimasi antara variabel pendapatan terhadap variabel konsumsi belanja modal, konsumsi pangan, konsumsi non pangan dan konsumsi total pada tabel 9 sebagai berikut:

Tabel 9. Hasil Uji Linieritas Keluarga Non TKI

\begin{tabular}{llllll}
\hline No & Ket & t-statistik & Prob. & F-statistik & Prob. \\
\hline 1 & P-KBM & 5,213306 & 0,0000 & 27,17856 & 0,0000 \\
2 & P-KP & 2,455836 & 0,0166 & 6,031133 & $0,0166^{*}$ \\
3 & P-KNP & 0,133886 & 0,8939 & 0,017926 & $0,8939^{*}$ \\
4 & P-KT & 1,669892 & 0,0995 & 2,788539 & $0,0912^{*}$ \\
\hline
\end{tabular}

Sumber: Lampiran diolah, 2017

Berdasarkan tabel diatas dapat di jelaskan bahwa nilai probability F-statistik pada persamaan pendapatan terhadap konsumsi barang modal sebesar 0.0000 lebih kecil dari nilai 0.05 , artinya model tersebut tidak berbentuk fungsi linier. Pada persamaan kedua pengaruh pendapatan terhadap konsumsi pangan nilai probability F-statistik sebesar 0.0166 lebih besar dari 0.05 , artinya model tersebut berbentuk fungsi linier. Pada persamaan ketiga pengaruh pendapatan terhadap konsumsi non pangan nilai probability F-statistik sebesar 0.8939 lebih besar dari 0.05 artinya model tersebut berbentuk fungsi linier. Dan untuk persamaan terakhir, pengaruh pendapatan terhadap konsumsi total nilai probability Fstatistik sebesar 0.0912 lebih besar dari 0.05 artinya model tersebut berbentuk fungsi linier.

\section{Pembahasan}

Hasil estimasi model regresi linier sederhana menunjukkan bahwa Variabel remiten berpengaruh positif terhadap konsumsi belanja modal, dan variabel remitan berpengaruh signifikan terhadap konsumsi belanja modal, Ini artinya semakin besar jumlah remitan yang dikirim oleh TKI ke daerah asal maka semakin besar pula konsumsi belanja modal yang dikeluarkan oleh keluarga TKI. Variabel remitan berpengaruh positif terhadap konsusmi pangan dan variabel remitan berpengaruh signifikan terhadap konsumsi pangan, ini artinya semakin besar jumlah remitan yang dikirim oleh TKI ke daerah asal semakin besar pula konsumsi pangan yang dikeluarkan oleh keluarga TKI. Variabel remitan berpengaruh positif terhadap konsumsi non pangan dan variabel remitan berpengaruh signifikan terhadap konsumsi non pangan, artinya semakin besar jumlah remitan yang dikirim oleh TKI ke daerah asal semakin besar pula konsumsi non pangan yang dikeluarkan oleh keluarga TKI.Variabel remitan berpengaruh positif terhadap konsumsi total dan variabel remitan berpengaruh signifikan terhadap konsumsi total , artinya semakin besar jumlah remitan yang dikirim oleh TKI ke daerah asal semakin besar pula konsumsi total yang dikeluarkan oleh keluarga TKI. Hal ini sesuai dengan pendapat Hugo (1978) dalam Effendi,2004: 222-223) yaitu sebagian besar remitan digunakan untuk memenuhi kebutuhan sehari-hari keluarga, biaya pendidikan anak, untuk membeli barang-barang konsumsi lainnya dan perbaikan rumah. Semakin besar kebutuhan hidup dan tanggungan keluarga untuk mempertahankan hidupnya maka semakin besar pula remiten yang akan dikirim TKI ke daerah asal untuk kebutuhan keluarganya.

Variabel pendapatan berpengaruh positif terhadap konsumsi belanja modal dan variabel pendapatan juga berpengaruh signifikan terhadap konsumsi belanja modal , artinya semakin besar jumlah pendapatan yang diterima oleh masyarakat keluarga non TKI semakin besar pula kesempatan masyarakat untuk mengkomsumsi belanja modal. Variabel pendapatan berpengaruh positif terhadap konsumsi pangan dan varaibel pendapatan signifikan terhadap konsumsi pangan, artinya semakin besar jumlah pendapatan yang diterima oleh masyarakat keluarga non TKI semakin besar pula konsumsi pangan yang di keluarkan oleh keluarga non TKI. Variabel pendapatan berpengaruh positif terhadap konsumsi non pangan dan variabel pendapatan berpengaruh signifikan terhadap konsumsi non pangan, artinya semakin besar jumlah pendapatan yang diterima keluarga non TKI semakin besar pula konsumsi non pangan yang dikeluarkan oleh keluarga non TKI. Variabel pendapatan juga berpengaruh positif terhadap konsumsi total dan variabel pendapatan berpengaruh signifkan terhadap konsumsi total, artinya semakin besar jumlah pendapatan yang diterima oleh masyarakat keluarga non TKI semakin besar pula konsumsi total yang dikeluarkan oleh keluarga non TKI.

\section{Simpulan}

Berdasarkan teori, hasil analisis data, dan pembahasan mengenai pengaruh remiten terhadap konsumsi barang modal, konsumsi pangan, konsumsi non pangan, dan konsumsi total keluarga TKI, dan pengaruh pendapatan terhadap konsumsi barang modal , konsumsi pangan, konsumsi non pangan dan konsumsi total keluarga non TKI di Desa Curahnongko Kecamatan Tempurejo Kabupaten Jember maka dapat diambil berbagai kesimpulan diantaranya sebagai berikut:

1. Konsumsi keluarga TKI dan konsumsi keluarga Non TKI mempunyai variasi keragaman yang berbeda. Konsumsi keluarga TKI menggunakan uang remitan yang di kirim oleh TKI ke daerah asal untuk konsumsi barang modal, konsumsi pangan, dan konsumsi non pangan. Akan tetapi sebagian besar remitan tersebut digunakan untuk konsumsi barang 
modal. Konsumsi barang modal di gunakan untuk memperbaiki kehidupan di masa yang akan datang, jika TKI sudah kembali ke daerah asalnya. Sedangkan keluarga non TKI menggunakan pendapatannya untuk memenuhi keragaman konsumsi keluarga nya. Akan tetapi sebagian besar pendapatan keluarga non TKI digunakan untuk konsumsi pangan. Untuk konsumsi yang lainnya bisa keluarga non TKI penuhi jika mendapatkan pendapatan tambahan.

2. Hasil pengujian secara parsial, remitan berpengaruh positif dan signifikan terhadap konsumsi barang modal keluarga TKI, artinya semakin besar jumlah remitan yang di kirim ke daerah asal maka semakin besar pula jumlah pengeluaran belanja modal keluarga TKI, remitan berpengaruh positif dan signifikan terhadap konsumsi pangan keluarga TKI, artinya semakin besar jumlah remitan yang dikirim ke daerah asal maka semakin besar jumlah pengeluaran konsumsi pangan keluarga TKI, remitan berpengaruh positif dan signifikan terhadap konsumsi non pangan keluarga TKI, artinya semakin besar jumlah remiten yang dikirm ke daerah asal maka semakin besar jumlah pengeluaran konsumsi non pangan keluarga TKI, remiten berpengaruh positif dan signifikan terhadap konsumsi total keluarga TKI, artinya semakin besar jumlah remiten yang dikirim ke daerah asal maka semakin besar jumlah pengeluaran konsumsi total keluarga TKI.

3. Hasil pengujian secara parsial, pendapatan berpengaruh positif dan signifkan terhadap konsumsi barang modal keluarga non TKI, artinya semakin besar pendapatan yang diperoleh oleh keluarga TKI maka semakin besar pula pengeluaran untuk konsumsi belanja modal keluarga TKI, pendapatan berpengaruh positif dan signifikan terhadap konsumsi pangan keluarga non TKI, artinya semakin besar pendapatan yang diperoleh oleh keluarga non TKI maka semakin besar pula pengeluaran untuk konsumsi pangan keluarga non TKI, pendapatan berpengaruh positif dan signifikan terhadap konsumsi non pangan keluarga non TKI, artinya semakin besar pendapatan yang diperoleh oleh keluarga non TKI maka semakin besar pula pengeluaran untuk konsumsi non pangan keluarga TKI, pendapatan berpengaruh positif dan signifkan terhadap konsumsi total keluarga non TKi, artinya semakin besar pendapatan yang diperoleh oleh keluarga TKI maka semakin besar pula pengeluaran untuk konsumsi total keluarga TKI.

\section{Saran}

Berdasarkan pada kesimpulan mengenai pengaruh remiten terhadap konsumsi barang modal, konsumsi pangan, konsumsi non pangan, dan konsumsi total keluarga TKI dan pengaruh pendapatan terhadap konsumsi barang modal, konsumsi pangan, konsumsi non pangann dan konsumsi total keluarga non TKI di Desa Curahnongko Kecamatan Tempurejo Kabupaten Jember, maka saran yang dapat di sampaikan bagi pihak yang berkepentingan adalah sebagai berikut:

1. Untuk terus meningkatkan peran serta Tenaga Kerja Indonesia (TKI), pemerintah setempat bisa menfasilitasi dan melindungi para Tenaga Kerja Indonesia, sehingga para Tenaga Kerja Indonesia bisa terus menjadi dan meningkatkan devisa Negara dan terus meningkatkan pembangunan, terutama di daerah asal.

2. Untuk remitan yang dikirim harus bisa benar-benar dimanfaatkan untuk investasi jangka panjang, agar setelah kembali ke daerah asal para Tenaga Kerja Indonesia tidak merasa kesulitan lagi khususnya dibang perekonomian.

3. Pemerintah daerah meningkatkan perannya untuk membantu masyarakat lokal atau masyarakat yang tidak bekerja ke luar negeri dengan cara memperbanyak atau memperluas lapangan pekerjaan, baik dalam bentuk kerajinan tangan, home industry, dan lain-lain, sehingga msyarakat tidak hanya bergantung pada pertanian di daerah asal. Karena jika dilihat dari luas lahan pertanian, tidak sebanding dengan jumlah penduduk yang ada.

\section{Referensi}

Soeroto, 2002. Strategi Pembangunan dan Perencanaan Tenaga Kerja. Yogyakarta: BPFE Gajah Mada Universitas

Sukirno, Sadono. 2011. Makroekonomi Teori Pengantar. Jakarta: PT RajaGrafindo Persada

Sumarsono, S.2003, Ekonomi Sumber Daya Manusia. Yogyakarta: Graha Ilmu.

Todaro, Michael P. 1999. Ekonomi Untuk Negara Bekermbang. Ahli Bahasan Agustinus Subekti. Edisi 3 Cetakan 1 Bumi Aksara: Jakarta.

http://wijayanomics.wordpress.com/2013/03/29/teori-ekonomi-keynes/ (1juni2017). 